\title{
Dentro de la Revolución: Mobilizing the Artist in Alfredo Sosa Bravo's Libertad, Cultura, Igualdad (1961)
}

\author{
Liuba González de Armas
}

Egalitarian access to culture was one of the promises of the 1959 Cuban Revolution. Concurrent with this commitment was the established role of Cuban artists and intellectuals as ideological vanguard, which enabled them to shape and muster public support for the emerging socialist society. These factors place cultural policy and its enactment at the core of an understanding of politics and the state in post-revolutionary Cuba. Adopting cultural geographer Gillian Rose's notion of three sites of meaning, this text examines Alfredo Sosa Bravo's woodcut print Libertad, Cultura, Igualdad (1961) as both reflective and constitutive of Cuba's cultural policy of the early 1960s. I argue that Libertad, Cultura, Igualdad (1961) functions as a multi-layered work of propaganda whose conditions of creation, content, and exhibition reinforce a relationship of collaboration between artists and the state-run cultural institutions of postrevolutionary Cuba.

In the words of sociologist Sujatha Fernandes, the arts are not simply a representation of Cuban society; cultural production is rather constitutive of society and the changes taking place within it. ${ }^{1}$ An examination of the artistic projects of early post-revolutionary Cuba is thus crucial to understanding the processes which formulated hegemonic conceptions of art and culture. One of the central questions in this area is the role of artists and intellectuals in the emerging socialist society. The object of this study is Libertad, Cultura, Igualdad (1961, Fig. 1), a woodcut print by self-taught Cuban artist Alfredo Sosa Bravo (b. 1930) which explicitly addresses the duty of the intellectual to mobilize in the face of imperialist domination. ${ }^{2}$ Libertad, Cultura, Igualdad is the thirty-fourth print in the largely unexamined Declaración de La Habana set, which comprises forty woodcuts produced by twelve Cuban artists under the direction of the Consejo Nacional de Cultura (National Council for Culture) in 1961. Each print interprets and illustrates a section of the text of the First Declaration of Havana, a landmark address delivered by Fidel Castro before thousands at Havana's Plaza Cívica (Civic Square) on September 2,

\footnotetext{
${ }^{1}$ Sujatha Fernandes, Cuba Represent! Cuban Arts, State Power, and the Making of New Revolutionary Cultures (Durham: Duke University Press), xi-xiii.

${ }^{2}$ This is a descriptive title based on the most prominent text in the work, which translates to "Liberty, Culture, Equality".
} 
1960. ${ }^{3}$ The Declaración de La Habana prints were first publicly exhibited in 1961 at the Palacio de Bellas Artes in Old Havana. ${ }^{4}$

Being conscious of the constitutive nature of cultural production in Cuban society, I have adopted a theoretical framework that approaches objects as agents of meaning. Cultural geographer Gillian Rose proposes that objects derive meaning over three sites: production, the image, and reception..$^{5}$ I adopt Rose's framework of three sites of meaning to interrogate Sosa Bravo's print with the goal of understanding the mechanisms by which Cuban artists became involved in the emerging socialist society of the early 1960s.

In Rose's theory, the site of production encompasses by whom, for whom, how, and why an object is made. Production thus involves not only artists and their intentions but also their patrons and broader social, political, and economic contexts. I approach the site of production from the realm of cultural policy through discourse analysis, examining official statements on the social role of the arts and artists in post-revolutionary Cuba, the stated purpose and power of cultural institutions, and artists' responses to these directives.

The site of the image refers to all information that can be gained from the object alone. These include material (or medium); a work's formal aspects, such as dimensions, colour, and composition; and semantic elements such as visual metaphors and text. In this section I situate the print's material and mode of production in the context of accessible, politically-engaged art. Further, I interpret the print's composition and iconography, and interrogate the accompanying text in order to access the print's visual messages of collectivism, mass mobilization, and the artist as social vanguard.

The site of reception describes the realm of viewer interaction with the object, including where, when, and to whom the work is displayed, as well as how it may be interpreted. Given the absence of information on the 1961 exhibition of the Declaración de La Habana set at the Palacio de Bellas Artes (Palace of Fine Arts), I draw from the context and formal characteristics of Sosa Bravo's print to speculate how viewers may have experienced it. Additionally, I examine how the choice of exhibition venue illustrates the

\footnotetext{
${ }^{3}$ The site of this address became central to the revolutionary government's public image and was officially renamed Plaza de la Revolución (Revolution Square) on July 16, 1961.

${ }^{4}$ Nathalie Bondil, Cuba: Art and History from 1868 to Today. (Montreal: Montreal Museum of Fine Arts), 186.

${ }^{5}$ Gillian Rose, "Towards a Critical Visual Methodology," in Visual Methodologies: An Introduction to Researching with Visual Materials (London: Sage, 2012), 5-32.
} 
revolutionary government's simultaneous democratization of the arts and reshaping of the national visual arts canon. Through these observations I argue that Alfredo Sosa Bravo's Libertad, Cultura, Igualdad functions as a multi-layered work of propaganda whose conditions of creation, content, and exhibition reinforce a relationship of collaboration between artists and the state-run cultural institutions of post-revolutionary Cuba.

With the triumph of the Cuban Revolution in 1959, the nation experienced drastic political, economic, and social change. At the heart of the Revolutionary government's social reform, according to revolutionary leader and Prime Minister Fidel Castro, was the goal of "developing art and culture... so they may become a true patrimony of the people." "Like education and basic healthcare, art was to become a right enjoyed by all citizens. Given its aim to broaden access to cultural goods, the aforementioned goal fits what political scientist Kevin V. Mulcahy describes as a policy of democratization of culture. ${ }^{7}$ Cuba's cultural policy between 1959 and 1971 is further defined in a speech delivered by Castro at a writers' forum at Havana's Biblioteca Nacional "José Martí" on June 30, 1961. ${ }^{8}$ The speech, titled Palabras a los intelectuales (Words to the Intellectuals), famously states "dentro de la Revolución todo; contra la Revolución nada" (within the Revolution, everything; against the Revolution, nothing), referring to the rights of intellectuals in post-revolutionary Cuba. ${ }^{9}$ Two contradicting interpretations of this statement prevail. The first postulates that the statement indicates that all works of art have an obligation to further the cause of the Revolution. The other, the more popular interpretation in publications by cultural institutions contemporaneous to the speech, claims that all forms of cultural production are fostered on the condition that they do not threaten the cause of the Revolution. This equivocal standard made the extent of artists' creative liberty in post-revolutionary Cuba uncertain. ${ }^{10}$

The Revolutionary government's policy of cultural democratization drove the creation of organizations such as the Instituto Cubano del Arte e Industria Cinematográficos (ICAIC, 1959), Casa de las Américas (1959), and the Unión de Escritores e Artistas

\footnotetext{
${ }^{6}$ My translation. Fidel Castro Ruz, "Palabras a los intelectuales," in Revolución, Letras, Arte, edited by Virgilio López Lemus, (Havana: Editorial Letras Cubanas, 1980), 15.

${ }^{7}$ Kevin V. Mulcahy, "Cultural Policy," in Handbook of Public Policy, ed. Guy B. Peters and Jon Pierre, (London: Sage Publications, 2006), 265.

8 Castro Ruz, "Palabras a los intelectuales," 15.

9 Ibid.

10 Innocuous works like Sabá Cabrera Infante's documentary P.M. (1961) were subjected to ICAIC's censorship without explanation beyond that the film represented scenes of decadence not in keeping with the new revolutionary ideal. Guillermo Cabrera Infante, "Mea Cuba (Excerpt)," in The Cuba Reader: History, Culture, Politics, ed. Aviva Chomsky, Barry Carr and Pamela Mara Smorkaloff (Durham: Duke University Press, 2003), 481-487.
} 
Cubanos (UNEAC, 1961), whose goals included facilitating the creation and dissemination of cultural goods and services while regulating the discourse on the role of culture in socialist Cuba. ${ }^{11}$ Among these organizations was the Consejo Nacional de Cultura (National Council for Culture), which oversaw the production of the Declaración de La Habana print set. ${ }^{12}$ The Consejo was founded on January 4, 1961 by Law 926 with the purpose of "planning, orienting and directing all cultural activities by official institutions... with the aims of responding to the State's cultural policy.",13

Given the absence of a robust national manufacturing industry, Cuban artists were frequently dependent on imported art materials, including pigments, art-grade paper, and technical equipment. With the nationalization of US-based businesses in 1960, importing and access to art supplies became largely regulated by the state and its cultural organs. Consequently, artists did not necessarily face direct censorship but rather could be subjected to denial of access to the means to produce their work. ${ }^{14}$ This relationship of potential material dependency may have influenced artists' decisions to publicly espouse pro-revolutionary views and make these the subject of their work. ${ }^{15}$ Libertad, Cultura, Igualdad is the product of a complex material and ideological symbiosis between artists and institutions guided by a cultural policy which - though presumably non-prescriptive - favoured political, populist, and pro-revolutionary work. By shaping public discourse on what it meant to be an artist in socialist Cuba through patronage, public programming, and publications, organizations like the Consejo Nacional de Cultura influenced artists' individual and collective self-perception. Consequently, it is not surprising that Sosa

${ }^{11}$ The organizations listed are the Cuban Institute for the Arts and Cinematographic Industry, the House of the Americas, and the Union of Cuban Writers and Artists. Though their roles overlapped at times, these can be understood as dealing with film, cultural diplomacy, and representing and coordinating the cultural workforce respectively. Jaime Sarusky and Gerardo Mosquera, The Cultural Policy of Cuba. Studies and Documents on Cultural Policies (Paris: UNESCO, 1979), 28-39.

${ }^{12}$ Declaración de La Habana: 40 xilografías cubanas, (Havana: Consejo Nacional de Cultura, 1961).

${ }^{13}$ My translation, from Osvaldo Dorticós Torrado, Fidel Castro Ruz, and Armando Hart Dávalos, "Ley 926: Fundación del Consejo Nacional de Cultura," in Gaceta Oficial de la República de Cuba, Tomo Quincenal Número 1, Número Anual 5 (Havana: Republic of Cuba, 1961), 289.

${ }^{14}$ Official and unofficial forms of censorship included overt proscription by official regulating bodies; appeasement through assignment to high-ranking positions within the cultural industry; and denial of access to equipment and resources. Cabrera Infante, "Mea Cuba (Excerpt)," 481-487.

${ }^{15}$ Yet, as Judith Weiss argues, the power of cultural institutions should not be taken to mean that all or even most artists were coerced into sympathizing with the revolutionary government and producing propagandistic work. The sheer volume and diversity of views on the role of culture and the intellectual in socialist society published in independent and state-funded periodicals such as Casa de las Américas and Lunes de Revolución reveal a vibrant discourse largely driven by freely-engaged artists and intellectuals. The cultural reviews of early 1960s Cuba reflect an ideologically-diverse community, one with critical, committed, and even revolutionary artists. Judith A. Weiss, Casa de las Américas: An Intellectual Review in the Cuban Revolution (Chapel Hill, NC: Estudios de Hispanófila, 1977), 27-34. 
Bravo's Libertad, Cultura, Igualdad offers a resolute view on what it means to be an artist in Cuba: revolutionary and ready to fight opposition.

Despite the wealth of meaning drawn from the site of production, Libertad, Cultura, Igualdad is not reducible to its historical context. Material, visual, and textual content communicate revolutionary engagement so that if presented to an uninformed audience the print still communicates notions of sacrifice, collectivism, and mass mobilization. Given Sosa Bravo's explicit partnership with the Consejo Nacional de Cultura in the creation of Libertad, Cultura, Igualdad, it is curious that the print uses cardstock - an ordinary, inexpensive material. While economic factors may have guided this choice, the material's suggestion of accessibility is palpable. Humility of material frames Sosa Bravo's work as attainable to all Cubans. The print's value is unrelated to capitalist markers of worth such as scarcity or inaccessibility, but rather lies in its capacity to communicate with the average Cuban. This feature distinguishes the Revolutionary government's patronage of the arts from the ostentatious beautification projects of prerevolutionary Cuba.

Libertad, Cultura, Igualdad is a woodcut print. Woodcut is an inexpensive relief printing technique that uses carved blocks of wood to transfer an image onto a flat surface. Given its relatively low cost of production, expressiveness, and ease of reproduction, this technique became associated with populism, left-wing politics, and anti-imperialist activism throughout Latin America in the early twentieth century. ${ }^{16}$ Mexico's Taller de Gráfica Popular (est. 1937) - whose work was exhibited in Havana in 1940 - and neighbouring Puerto Rico's Centro de Arte Puertorriqueño (est. 1950) are chief exponents of this artist-activist tradition and would have been familiar to Cuban artists in the 1960s. ${ }^{17}$ The print's popular medium prefaces a message of art-based political engagement which would have been readily understood by its contemporaries.

Alfredo Sosa Bravo's Libertad, Cultura, Igualdad can be visually understood as a scene of confrontation between an armed group of people and an unspecified enemy. The fixed rightward gaze, open mouths, contracted shoulders, and extended arms of the figures communicate a combative stance which is reinforced by the tense rectilinear forms that

\footnotetext{
${ }^{16}$ Tomás Ortiz, Manual de xilografia. 1st ed. (Mexico City: Universidad Nacional Autónoma de México, 1968), 5-7.

17 The Taller de Gráfica Popular (People's Print Workshop) of Mexico and the Centro de Arte Puertorriqueño (Centre for Puerto Rican Art) were artist-run organizations which promoted distinctly populist and nationalist print art in their respective countries. Ibid, 6; Roberto Cobas Amate, ed., Museo Nacional De Bellas Artes, La Habana, Cuba: Colección De Arte Cubano (Barcelona: Editorial "Sa Nostra", 2001), 20; La xilografía en Puerto Rico, 1950-1986 (Recinto de Río Piedras, Puerto Rico: Universidad de Puerto Rico, 1986), 17-24.
} 
compose them. The figures are identical but for a few salient features: a straw hat, baldness and wrinkles, long hair, and dark skin tone. These representational choices serve to simultaneously suggest equality and diversity on the basis of socioeconomic status, age, gender, and ethnicity. This interpretation is reinforced by a passage from the 1960 Declaración de La Habana on the bottom right of the image, which pronounces "the duty of workers, peasant farmers, students, intellectuals, black and indigenous people, youth, women, and the elderly to fight for their economic, political, and social rights."18 The stereotypical markers of trade, age, gender, and race, coupled with the combative stances of the figures serve to literally reproduce the accompanying text, translating its metaphor of societal change as battle to a visual modality. ${ }^{19}$ This call for the mobilization of various marginalized groups in a common cause situates intellectuals as one of the many sectors of society mobilized toward their own liberation. No single figure in the group can be conclusively identified as the intellectual: she or he might be any or all of the figures.

Straight and roughly horizontal lines, which read as weapons, extend from the figures' hands to direct the viewer's gaze from left to right towards ragged banners bearing the words Libertad, Cultura, and Igualdad (Liberty, Culture, and Equality). This three-word motto reflects the language used by the state to define its sociopolitical aims in texts such as Palabras a los intelectuales. While the ideals of liberty and equality are firmly established in international revolutionary rhetoric, the word culture presents a more enigmatic proposition. ${ }^{20}$ The representation of culture as a weapon of liberation wielded by the masses reinforces the metaphor of the reforging of Cuban society as a battle of ideas to be fought by artists and intellectuals. While the revolutionaries are clearly represented by a mass of eight human figures on the left half of the image, the right side prominently features empty white space: the enemy exists just beyond the image frame. This absence serves to frame the discourse of revolutionary struggle as a process dependent on the efforts of actively-engaged people. The resulting message is a resounding but vague call to mass mobilization which refrains from identifying a particular enemy.

${ }^{18}$ My translation from the original: "[1]a Asamblea General Nacional del Pueblo de Cuba postula: el deber de los obreros, de los campesinos, de los estudiantes, de los intelectuales, de los negros, de los indios, de los jóvenes, de las mujeres, de los ancianos, a luchar por sus reivindicaciones económicas políticas y sociales". From Declaración de La Habana: 40 xilografias cubanas.

${ }^{19}$ One notable point of disparity between the illustration and the text is the number of figures present. While the text mentions nine distinct groups of people, the print depicts only eight figures. Perhaps Sosa Bravo has chosen to omit the artist (and intellectual) in favour of representing him through his indexical trace - the work of art - instead. This disparity warrants its own separate analysis.

${ }^{20}$ For example, the motto Liberté, Egalité, Fraternité, coined by French revolutionary Maximilien Robespierre. 
Sosa Bravo's Libertad, Cultura, Igualdad is a call for Cuban artists to lend a hand in service of the nascent socialist state. The print presents its argument in five steps through material, technique, representation of figures, text, and formal composition. The work's inexpensive cardstock material asserts its accessible nature, while the woodcut printing technique alludes to a pan-American legacy of activist printmaking which places artists at the head of revolutionary struggle. A diverse but unified group of combative figures establishes a visual metaphor of societal change as armed struggle. This metaphor is supported by the textual representation of liberty, culture, and equality - tenets of the new state - as weapons. Lastly, the conspicuously empty space on the right marks the enemy's absence from the picture plane. This compositional choice emphasizes the centrality of revolutionaries to the struggle while enabling ambiguity in terms of what revolutionaries are asked to mobilize against. Libertad, Cultura, Igualdad functions as a visual call to action where the combatants and their weapons are defined, but the enemy is not.

Formal and visual elements interact with the exhibition context to give form to individual encounters and interpretations of an object. The scale of Sosa Bravo's print permits simultaneous viewing by several people, yet the small font used for the text on the bottom right demands physical proximity. In keeping with other democratising practices of the revolutionary government, this spatial privileging of image over text favours a visual experience which would have been accessible to an illiterate public. ${ }^{21}$ Interrogating the print's illustration in relation to its accompanying text would require time and more intimate interaction with the work. Differences in the scale of image and text exacerbate the division between visual appreciation of the image and critical engagement with it, where economy of time and cognitive resources favour the first, rather superficial form of interaction. Given these formal characteristics, the sequential placement of the Declaración de La Habana prints within the exhibition venue would have prompted viewers to unquestioningly appreciate the images rather than expend time and effort critically engaging with each one of them. Moreover, the repetition of key themes across the series would serve to affirm the images' messages by building consensus and familiarity. A sequential experience of the works would thus effectively encourage viewers to absorb and embrace the goals of the Revolution.

In addition to scale, directionality also would have influenced visitors' interactions with the work; the left-to-right movement evoked by the rightward-facing figures and their

\footnotetext{
${ }^{21}$ Prior to 1959 , Cuba's official literacy rate was between $60 \%$ and $76 \%$, and while the Campaña Nacional de Alfabetización (National Literacy Campaign) had begun on January 1 of 1961, it would not end until December 22 of the same year. Jaime Sarusky and Gerardo Mosquera, The Cultural Policy of Cuba, 13-14.
} 
weapons in Libertad, Cultura, Igualdad creates the potential for a compelling, immersive experience. If the prints were exhibited sequentially from left to right or clockwise, as per exhibition conventions, visitors would approach the work from the side of the revolutionaries, thereby symbolically joining them. ${ }^{22}$ This compositional choice would elicit tacit compliance with the work's call to mobilization by resignifying the act of traversing a gallery to mean joining a political and ideological battle. Consuming revolutionary culture momentarily transforms viewers into revolutionaries.

The first known exhibition of the Declaration of Havana woodcuts - and among them Sosa Bravo's Libertad, Cultura, Igualdad - took place in 1961 at the Palacio de Bellas Artes. $^{23}$ The Palacio is a building within the Museo Nacional de Bellas Artes (MNBA, or National Museum of Fine Arts) complex exclusively dedicated to Cuban Art. Granted its current home on San Rafael street by dictator Fulgencio Batista in 1954 as a means of garnering public approval, the MNBA reflected Cuba's desire to legitimize its nationhood through the construction of a distinctly national Art. ${ }^{24}$ By 1959, the MNBA had hosted a number of prestigious national and international exhibitions and was held up as a conservative bastion of national cultural patrimony. ${ }^{25}$ Having their work exhibited at the Museo Nacional de Bellas Artes granted the artists of the Declaración de La Habana series significant professional prestige. This gesture would have conspicuously signaled the benefits of working in service of the Revolution to other artists, and perhaps incentivized such partnerships.

Cultural institutions of the scale of the Museo Nacional de Bellas Artes enjoy the capacity to shape a nation's art history by inducting or expelling artists and their works from the national canon through exhibitions, publications, and other discursive means. With this capacity in mind, the exhibition of contemporary, revolutionary woodcuts such as Libertad, Cultura, Igualdad at the Palacio de Bellas Artes signaled the Revolution's appropriation and democratization of an old bourgeois institution of Batista's Cuba. Artists, critics, curators, and cultural professionals would have seen this event as a paradigm shift. Thus this exhibition would have prompted artists to collaborate with the state not only through the promise of grand exhibition venues and professional prestige, but also by hinting at the possibility of more direct control over the future of Cuban art.

\footnotetext{
${ }^{22}$ Given the lack of information on the design of the 1961 exhibition of the Declaración de La Habana prints, this analysis of exhibition design strategies is consciously speculative, and rather aims to theorize how the public may have interacted with Sosa Bravo's print.

${ }^{23}$ Bondil, Cuba: Art and History from 1868 to Today, 46.

${ }^{24}$ Cobas Amate, Museo Nacional de Bellas Artes, La Habana, Cuba: Colección de Arte Cubano, 20-22.

25 Ibid, 24.
} 
This analysis of Alfredo Sosa Bravo's Libertad, Cultura, Igualdad reveals multiple strategies through which Fidel Castro's revolutionary government promoted the mobilization of artists and intellectuals in the service of the Cuban Revolution. State-run cultural organizations played a central role in Cuba's post-revolutionary cultural industry by acting as mediators between artists and material and institutional resources. These institutions played an instrumental role in shaping discourse surrounding the roles of art and artists in socialist Cuba, a matter which Libertad, Cultura, Igualdad overtly addresses through its visual call to join the national struggle. Further, state-sponsored exhibitions gave the public a chance to directly engage with revolutionary cultural goods and potentially be drawn into their narratives. Exhibitions also signaled to artists the incentives of working in service of the Revolution, these being professional prestige, access to larger publics, and the potential to shape the canon of Cuban Art. Sosa Bravo's Libertad, Cultura, Igualdad not only aims to visually answer the question of the role of the artist in post-revolutionary Cuba, but constitutes a fascinating portion of a discursive process by artists, cultural institutions, and the Cuban public to make sense of themselves and culture in the new socialist reality. 
Bibliography

Declaración de La Habana; 40 xilografías cubanas. Havana: Consejo Nacional de Cultura, 1961.

La xilografía en Puerto Rico, 1950-1986. Recinto de Río Piedras, Puerto Rico: Universidad de Puerto Rico, 1986.

Bondil, Nathalie. Cuba: Art and History from 1868 to Today. Montreal: Montreal Museum of Fine Arts, 2009.

Cabrera Infante, Guillermo. "Mea Cuba (Excerpt)." In The Cuba Reader: History, Culture, Politics, edited by Chomsky, Aviva, Barry Carr and Pamela Mara Smorkaloff, 723. Durham: Duke University Press, 2003.

Castro Ruz, Fidel. "Palabras a los intelectuales." In Revolución, Letras, Arte, edited by López Lemus, Virgilio, 616. Havana: Editorial Letras Cubanas, 1980.

Cobas Amate, Roberto, ed. Museo Nacional De Bellas Artes, La Habana, Cuba: Colección De Arte Cubano. Barcelona: Editorial "Sa Nostra", 2001.

Dorticós Torrado, Osvaldo, Fidel Castro Ruz, and Armando Hart Dávalos. "Ley 926: Fundación del Consejo Nacional de Cultura." In Gaceta Oficial de la República de Cuba. Havana: Republic of Cuba, 1961.

Fernandes, Sujatha. Cuba Represent! Cuban Arts, State Power, and the Making of New Revolutionary Cultures. Durham: Duke University Press, 2008.

Mulcahy, Kevin V. "Cultural Policy." In Handbook of Public Policy, edited by Peters, B. Guy and Jon Pierre, 512. London: Sage Publications, 2006.

Ortiz, Tomás. Manual De Xilografía. 1st ed. Mexico City: Universidad Nacional Autónoma de México, 1968.

Rose, Gillian. "Towards a Critical Visual Methodology." In Visual Methodologies: An Introduction to Researching with Visual Materials, 386. London: Sage, 2012.

Sarusky, Jaime and Gerardo Mosquera. The Cultural Policy of Cuba. Studies and Documents on Cultural Policies. Paris: UNESCO, 1979. 
Weiss, Judith A. Casa De Las Américas: An Intellectual Review in the Cuban

Revolution. Estudios de Hispanófila. Vol. 44. Chapel Hill, NC: Estudios de Hispanófila, 1977. 
Appendix

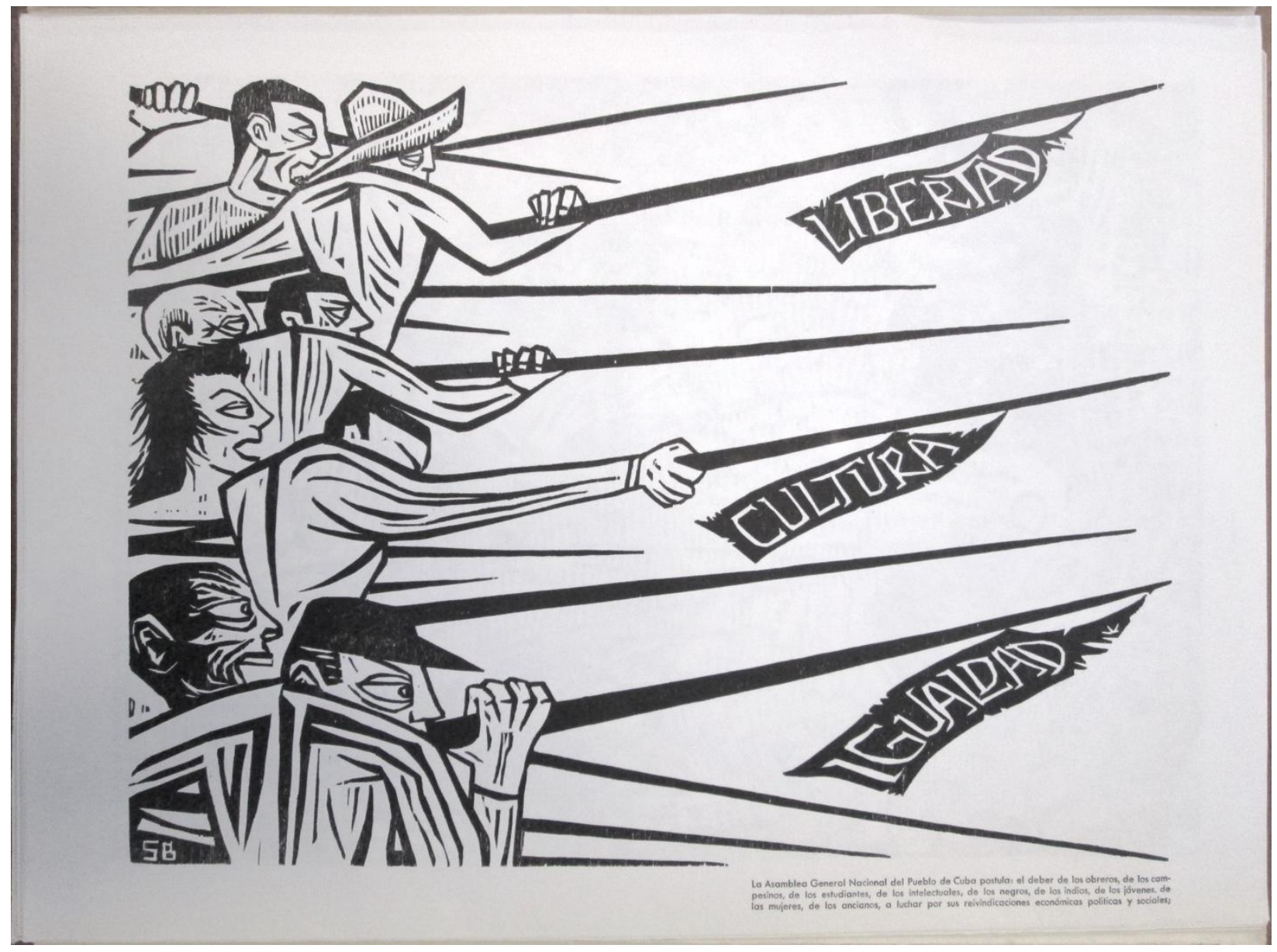

Fig. 1. Alfredo Sosa Bravo. Libertad, Cultura, Igualdad, 1961. Woodcut, letterpress, 35.5 $\mathrm{cm}$ x $48.3 \mathrm{~cm}$. Nettie Lee Benson Latin American Collection, The University of Texas Libraries, Austin. Photograph: The author.

Note for researchers: Editions of the Declaración de La Habana woodcuts are available at libraries and research centres in several US American universities, including The University of Texas at Austin; Cornell; Columbia; and the Universities of Miami, Florida, and California. A set owned by the University of Kansas was notably transferred to the Spencer Museum of Art in 2003. 